Riitta Lähdemäki, Ulla Nygrén ja Kimmo Tuominen

\title{
VISIOSTA VAATIMUSMÄÄRITTELYYN, AALLOKOSTA ASIAKKAILLE: SUOMEN ALMA-KIRJASTOT VUONNA 2021
}

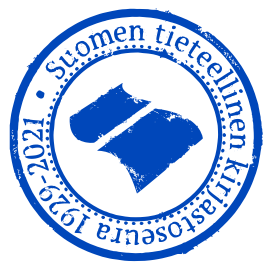

Alma-kirjastojen yhteinen visionti alkoi vuonna 2018, kun havaittiin ettei yksi järjestelmä riittäisi täyttämään kaikkien Suomen korkeakoulukirjastojen tarpeita. Alman käyttöönotto toteutettiin kahdessa aallossa: ensimmäinen aalto siirtyi tuotantokäyttöön joulukuussa 2019 ja toinen elokuussa 2020. Yhteistyö on jatkunut käyttöönotton jälkeenkin: Alma yhdistää kirjastoja niin kansallisesti kuin kansainväliselläkin tasolla.

A lma-kirjastojen yhteistyön lähtökohtana on järjestelmävisio, jonka laadimme vuoden 20 I 8 alkupuolella. Visiomme nojautuu ajatukseen yhtenäisestä, digitaalisen aineiston työnkulkuja tukevasta palvelualustasta, joka on suunnattu korkeakoulukirjastokäyttöön ja toimii pilvipalveluna (SaaS, Software as a Service). Vision ja siihen pohjautuvan vaatimusmäärittelyn avulla hankimme toimivan ja tuotantokäytössä olevan kirjastopalvelualustan, jolla on uskottavat referenssit ja vahva asema globaalissa kaupallisten kirjastojärjestelmien kentässä. Vastaisuudessa haluamme hyödyntää kaikki Alman tarjoamat kehitysmahdollisuudet.

\section{Kilpailutuksesta} käyttöönottoon

Yhteisen kirjastojärjestelmän hankintaan tähtäävässä kansallisessa hankkeessa tultiin vuoden 2018 alussa siihen lopputulemaan, että kirjastojen tarpeet poikkeavat toisistaan, eikä yksikään järjestelmäratkaisu palvele yhtä hyvin kaikkia kirjastoja. Alma-kirjastojen osalta yhteinen visiointi käynnistyi kolmen yliopistokirjaston (Helsinki, Tampere ja Turku) johtajien pohdinnasta ja kasvoi lopulta 28 organisaatiota kattavaksi hankintakonsortioksi.

Järjestelmän hankintaa ja käyttöönottoa koordinoimaan perustettiin ohjausryhmä, jossa olivat edustettuina hankkeessa mukana olevat kirjastosektorit (yliopisto-, ammattikorkeakouluja erikoiskirjastot). Käyttöönoton toteutuksesta kirjastoissa vastanneet projektipäälliköt muodostivat oman yhteistyöverkostonsa.

Järjestelmähankinnan edellyttämä kilpailutus perustui vaatimusmäärittelydokumenttiin, jonka rakentamiseen koko hankintakonsortio osallistui. Vaatimusmäärittelyn laadinnassa saatoimme hyödyntää laajasti kirjastojen teknistä ja substanssiosaamista, ja vaatimusmäärittelyn laadintaprosessi loi erinomaisen pohjan Alma-kirjastojen nykyiselle yhteistyölle.

Visiomme lähtökohtana oli, että järjestelmä muodostaa kokonaisuuden, johon on integroitu kansainvälinen tietämyskanta (кв), digitaalisten aineistojen hallintajärjestelmä (ERM) ja helppokäyttöiset analytiikkatoiminnal- 
lisuudet. Kilpailutuksen toteutti Turun yliopisto, ja sen voittajaksi valikoitui Ex Libriksen Alma. Alma on uuden sukupolven kirjastopalvelualustaratkaisu, joka vastasi niin tekemäämme vaatimusmäärittelyä kuin alkuperäistä visiotakin. Kukin hankintayksikkö allekirjoitti oman sopimuksensa Ex Libriksen kanssa.

Alma-järjestelmän käyttöönotto toteutettiin kahdessa aallossa: tuotantokäyttöön siirtyminen tapahtui joko joulukuussa 2019 (ensimmäinen aalto) tai elokuussa 2020 (toinen aalto). Oman kilpailutuksensa toteuttanut Aalto-yliopisto siirtyi Almaan viimeisenä Voyager-kirjastona joulukuussa 2020.

Vuonna 202 I Alma-kirjastoihin kuuluu suurin osa yliopistoista (Aalto-yliopisto, Helsinki, Itä-Suomi, Lappi, Lut, Oulu, Taideyliopisto, Tampere, Turku, Åbo Akademi) sekä useita ammattikorkeakouluja (Jyväskylä, Kajaani, Karelia, Oulu, Satakunta, Savonia, Seinäjoki, Tampere, Turku) ja erikoiskirjastoja (Eduskunnan kirjasto sekä esimerkiksi Helsingin yliopiston HELKA-järjestelmän liitännäiskirjastot: Kotimaisten kielten keskus, Museovirasto, Suomalaisen kirjallisuuden seura sekä Baltia-kirjasto ja Työväenliikkeen kirjasto). Osalla meistä on käytössä myös Almaan integroituva hakuliittymä Primo (Aalto, Helsinki, Itä-Suomi, LuT, Tampere, Turku); muut kirjastot ovat jatkaneet Finnan käyttämistä asiakasliittymänä. Kaikki Alma-kirjastot ovat mukana Finnan kansallisessa näkymässä ja Melindassa.

\section{Miltä Alma näyttää} asiakasnäkökulmasta?

Asiakkaan kannalta Alman näkyvyys on kytköksissä siihen, onko kirjaston käyttöliittymänä Primo vai Finna. Koska Finna on tuttu suurimmalle osalle Signumin lukijoista, keskitymme seuraavassa etenkin Primoon.

Primo on Alman yhden luukun hakupalvelu, joka nivoo yhteen kaikki organisaation tarjoamat tietoaineistot, niin painetut kuin digitaalisetkin. Primoa on kehitetty lähes vuosikymmen nimenomaan Alman asiakaskäyttöliittymäksi, joten hakusovellus loksahtaa sujuvasti kiinni isäntäohjelmistoonsa. Primo tarjoaa monipuolisia mahdollisuuksia hakunäkymien virittelyyn ja säätämiseen. Primon tekoäly seuraa myös itsenäisesti asiakkaiden hakukäyttäytymistä ja tekee siihen perustuvia johtopäätöksiä, joilla saattaa olla vaikutuksia esimerkiksi hakutulosten lajitteluun.

Asiakkaalle Primo tarjoaa käteviä ja tehokkaita hakumahdollisuuksia. Sähköisten artikkeleiden löytyminen helpottuu, kun yhdellä haulla löytyvät niin kokotekstit kuin kirjaston muutkin tietoaineistot. Hakuja on myös

\section{VOLTER-BINGO}

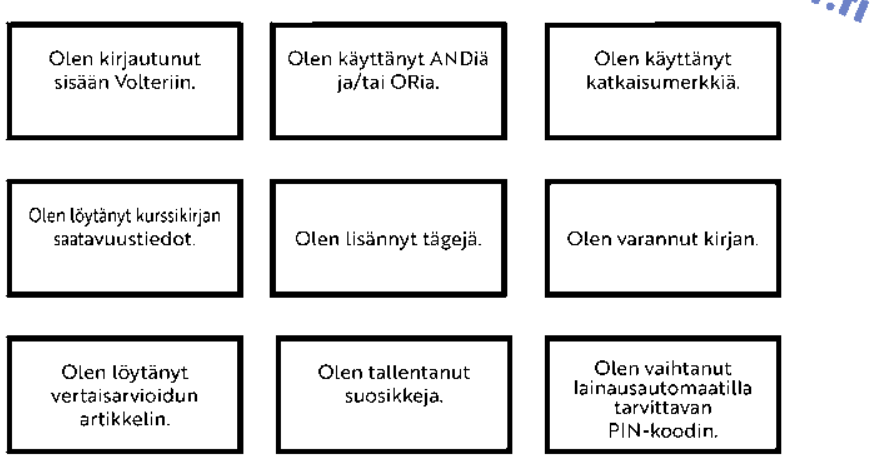




\section{0}

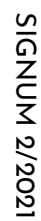

Helkan nykyinen Primo-näkymä. Liittymä mahdollistaa haun rajaamisen esimerkiksi vertaisarvioituihin tai avoimesti saatavilla oleviin artikkeleihin. mahdollista personoida ja nostaa itselle tärkeimmät aineistotyypit hakutulosten kärkeen, mikä on selkiyttänyt ja monipuolistanut tulosten käsittelyä. Englanninkieliset ja eräillä muilla valtakielillä tehdyt haut on Primossa optimoitu huomattavan pitkälle: Primo osaa huomioida taivutuksia, monikoita, synonyymejä ja yleisiä väärinkirjoituksia. Tekstipohjaisen haun lisäksi Primo tukee myös puheeseen perustuvaa hakua. Hakujen tulokset Primo esittää IFLA:n FRBR-vaatimuksen mukaisesti.

Alman ja Primon (ja kenties myös pandemian) yhteisvaikutuksena e-aineistojen käyttöluvut ovat kasvaneet kirjastoissamme harppauksenomaisesti. Käyttöliittymän tarjoamien mahdollisuuksien tutkinta ja käyttöliittymän virittely jatkuu Primoa käyttävissä Alma-kirjastoissa vastaisuudessakin. Osa kirjastoista on esimerkiksi jo toteuttanut selaushakua tukevan Browzine-ohjelmiston integroinnin Almaan, mikä on moninkertaistanut Browzinen käyttöluvut. Asiakkaamme voivat käyttää myös selainlaajennuksena toteutettua LibKey-komponenttia, joka muun muassa vähentää kokotekstin käyttöön- saamiseen liittyviä klikkauksia.

Painetun aineiston osalta Alma tehostaa aineistologistiikkaa. Esimerkiksi aineiston varaus ja nouto on mahdollista mistä kirjaston toimipisteestä tahansa. Tämä toiminnallisuus on ollut tärkeä myös koronapandemian aikana, jolloin kirjastojen kaikki toimipaikat eivät ole olleet auki.

Almassa on käytössä lomakkeita, jotka mahdollistavat välittömän kommunikoinnin ja automaattisen asiakasviestinnän. Esimerkiksi varausilmoitukset lähtevät varauksen aktivoituessa eivätkä seuraavana arkipäivänä.

\section{Miltä Alma näyttää kirjaston taustaorganisaation kannalta?}

Kehittyneiden rajapintaominaisuuksien vuoksi Alma integroituu sujuvasti esimerkiksi organisaation opiskelija- ja henkilöstöjärjestelmiin. Rajapintaintegraatiot mahdollistavat tietojen liikkumisen järjestelmästä toiseen, jolloin manuaalista työtä tarvitaan vähemmän. Turun yliopistolla, Certialla ja ExLibriksellä on parhaillaan käynnissä projekti, jossa rakennetaan toimivaa integraatioita SAP-talousjärjestelmän ja Alman välille. Alaprojektina toteu-

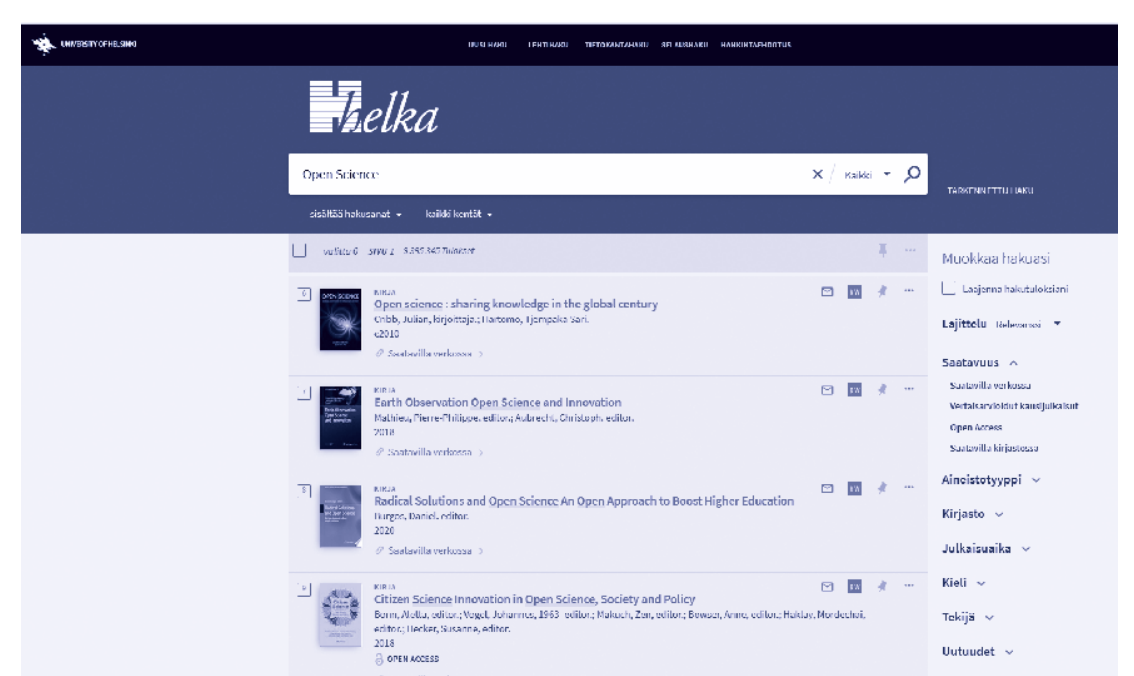


tetaan laskujen automaattinen siirtyminen välittäjän palvelusta Almaan EDI-toiminnallisuuden avulla.

Alma on kansainvälisesti laajasti käytössä, mikä mahdollistaa globaalin tiedon jakamisen ja esimerkiksi kuvailutietojen kopioinnin. Kirjastot hyötyvät konkreettisesti niistä datamassoista, joita Alma pitää sisällään. Alman community zone on käytännössä korvannut aiemmin tarvitun kopioluetteloinnin lisäohjelman (Bookwhere).

Alma-ympäristö tarjoaa kehittyneitä mahdollisuuksia tietoon perustuvalle johtamiselle, jota myös emo-organisaatiot kirjastoiltaan edellyttävät. Alma Analytics tekee mahdolliseksi kirjaston palvelujen ja investointien yhä tarkemman seurannan ja niiden suuntaamisen emo-organisaation tarpeisiin.

Palvelualustatyyppinen järjestelmä tehostaa kirjastojen työtä ja mahdollistaa myös totunnaisten työskentelyprosessien muuttamisen. Almassa esimerkiksi aineiston hankinnan ja kuvailun prosessit niveltyvät entistä kiinteämmin toisiinsa. Jokaisella kirjaston työntekijällä on mahdollisuus konfiguroida omaa Alma-näkymäänsä; käyttöliittymä tukee siis erilaisten työroolien ja -tehtävien tehokasta toteutusta. Almassa on myös kehittyneet työkalut massamuutoksiin, niin bibliografisten tietojen kuin asiakastietueidenkin osalta. Monipuoliset konfiguraatiomahdollisuudet, esimerkiksi lainauksen toiminnoissa, ovat olleet hyödyllisiä myös pandemian aiheuttamissa poikkeusoloissa.

Alkuperäisen visiomme tavoitteena oli tehostaa erityisesti elektronisen aineiston hallintaa ja käsittelyä, ja tämä tavoite on myös toteutunut. E-aineistojen aktivoinnit teemme Almassa, ja keskitetty indeksi on integroitu suoraan Almaan. Kaikki toiminnot löytyvät saman hallintaliittymän alta, mikä helpottaa työskentelyä sekä järjestelmän ylläpitoa kirjastoissa.

Pilvipalvelujärjestelmänä Alma pysyy ajan tasalla, eikä esimerkiksi Voyager-ympäristöstä tuttuja mutkikkaita päivitysprojekteja tarvita. Järjestelmän säännöllisen kuukausipäivitykset toki edellyttävät kirjastoilta erityistä valppautta ja päivitysten ripeää testaamista.

\section{Yhteistyömahdollisuuksia on runsaasti}

Alma-kirjastopalvelualusta yhdistää sitä käyttäviä kirjastoja niin kansallisesti ja pohjoismaisesti kuin eurooppalaisesti ja globaalistikin. Yhteistä puhuttavaa, pohdittavaa ja kehitettävää siis riittää.

Hankintaprosessi tiivisti Alma-kirjastojen verkostoja, ja yhteistyö on jatkunut järjestelmäkäyttöönottojen jälkeenkin. Olemme siirtyneet projektiorganisaatiosta syvenevän yhteistyön vaiheeseen. Haluamme oppia toisiltamme ja tehdä yhteistyötä muun muassa hankinta-, tilastointi-, kuvailu-,

Uuden palvelualustan avajaistunnelmissa on Turun yliopiston kirjastonjohtaja Ulla Nygrén ja Alma-projektin aikana palvelupäällikkönä toiminut Minna Niemi-Grundström. Visiointi uudesta järjestelmästä lähti liikkeelle Nygrénin, Niemi-Grundströmin ja Helsingin yliopiston kirjaston ylikirjastonhoitaja Kimmo Tuomisen keskusteluista. (Kuva: Ulla Nygrén) 
asiakaspalvelu- ja ERM-asioissa. Suomen Alma-kirjastoilla on myös oma ohjausryhmänsä (http://almakirjastot. fi/ohjausryhma/).

Pohjoismainen yhteistyö ruotsalaisten, norjalaisten ja tanskalaisten Alma-kirjastojen kanssa on alkanut lupaavasti; pandemia on tosin haitannut informaalimpaa verkostoitumista viime aikoina. Euroopassa ja maailmalla liikkuessa ei voi olla panematta merkille, että Alma on esimerkiksi monien huippuyliopistojen suosima kirjastojärjestelmä. Alma myös kehittyy jatkuvasti ja saa päivittyessään uusia ominaisuuksia, minkä vuoksi yhteistyö Ex Libriksen kanssa ja järjestelmän jatkokehitykseen vaikuttaminen on Alma-kirjastojen kannalta tärkeää. Ex Libris järjestää myös mielellään esimerkiksi webinaareja, esittelyjä ja kyselytunteja.

Kansalliskirjaston kanssa Alma-kirjastot tekevät yhteistyötä etenkin Finnan, Finton ja Melindan osalta. Haluamme myös tehdä yhteistyötä Varastokirjaston ja muiden kansallisten toimijoiden kanssa asiakastoimisen kaukopalvelun toteuttamisessa. Palvelun tulee onnistua taustajärjestelmien tasolla rajapintojen avulla (eikä esimerkiksi yksinomaan Finnassa tai Kohassa). Alman Resource Sharing -toi- minto tukee useita useita protokollia ja Iso:n standardia kaukopalvelupyyntöjen lähettämisessä ja vastaanottamisessa, eikä muun ohjelmiston kuin Alman käyttäminen tilaavan ja lähettävän kaukopalvelun hallinnoinnissa ole kirjastojemme kannalta mielekästä. Primo- ja Alma-kirjastot ovat niin Varastokirjaston kuin Kansalliskirjastonkin suurimpia yksittäisiä asiakkaita.

Vaikka Alma sisältääkin omaa analytiikkaansa, myös tilastotietojen siirtyminen mahdolliseen kansalliseen kirjastotilastointiratkaisuun on tärkeää. Huoli kansallisen tilastoinnin tulevaisuudesta yhdistää koko tieteellisten kirjastojen kenttää.

\section{Alman tulevaisuus}

Alma on kehittyvä kokonaisuus, ja Alma-kirjastot kehittyvät jatkuvasti kirjastopalvelualustan käyttäjinä. Vaikka Alma on jo tuotantokäytössä, sen kaikki hyödyt eivät ole vielä kirjastoissamme realisoituneet.

Vastaisuudessa niin tekoälyn kehittyminen kuin ohjelmistorobotiikkakin tarjoavat kiinnostavia mahdollisuuksia kirjastojen palveluiden kehittämiseen Alman avulla. Myös entistä jouhevamman mobiilikäytön mahdollistaminen on ajankohtaista monissa Alma- ja Primo-kirjastoissa.

Kirjoittajat ovat kirjastojensa johtajia. He ovat toimineet järjestelmähankinnan valmistelusta ja toteutuksesta vastanneessa ohjausryhmässä, ja Kimmo Tuominen on ollut ohjausryhmän puheenjohtaja vuosina 20 I 8-2020. Ulla Nygrén on vastannut ohjausryhmässä kilpailutuksen toteuttamisesta. Riitta Lähdemäki toimii parhaillaan Suomen Alma-kirjastojen ohjausryhmän puheenjohtajana.

\section{UlLA NygrÉN}

Turun yliopiston kirjasto ulla.nygren@utu.fi
RIITTA LÄHDEMÄKI

Tampereen yliopiston kirjasto riitta.lahdemaki@tuni.fi
Kimmo Tuominen

Helsingin yliopiston kirjasto kimmo.k.tuominen@helsinki.fi 